Jurnal InFestasi

Vol. 13 No. 2 Desember 2017

Hal. $344-353$

\title{
Perspektif Mahasiswa STIE Perbanas Surabaya atas Tax Evasion \\ Supriyati ${ }^{1}$ \\ ${ }^{1}$ STIE Perbanas, Surabaya
}

\section{A R T I C L E I N F O}

Key words:

Justice, Tax Administration Systems, Discrimination, Machiavellian, Tax Ethics.

\begin{abstract}
A B S T R A C T
State revenue comes from taxes currently occupies the largest portion of Revenue and Expenditure Budget (APBN). Various reforms have been undertaken by the Government in improving state revenue target. On the other hand, the taxpayer also thinks to minimize tax payments with the tax evasion. Tax evasion has been perceived as unethical because it violates the provisions of the existing taxation. This perception is influenced by factors justice, tax administration system, discrimination and Machiavellian. This is a quantitative research with the data collected from distributing questionnaires directly to the students of Bachelor of Accounting Perbanas Surabaya who are taking courses Tax Planning odd semester of 2015-2016. There were 183 respondents. Testing in this research using regression test. The results showed that the only the variable Machiavellian affects the perception of the ethics on tax evasion. Students perceived that tax evasion is an unethical act. This condition also supported their perception because they have not had experience in fulfillment of tax compliance, tax provisions normative or something that should be adhered to and support ethics courses and softskill development is done.
\end{abstract}

\begin{abstract}
A B S T R A K
Pendapatan negara yang berasal dari pajak saat ini memiliki porsi terbesar dalam APBN. Berbagai reformasi perpajakan telah dilakukan oleh pemerintah dalam meningkatkan target pendapatan. Di sisi lain, wajib pajak juga berpikir untuk meminimalkan pembayaran pajaknya melalui penggelapan pajak. Penggelapan pajak dipersepsikan sebagai hal yang tidak etis karena dinilai menciderai peraturan perpajakan yang telah ada. Persepsi tersebut dipengaruhi oleh faktor keadilan, sistem administrasi perpajakan, diskriminasi, dan aliran Machiavellian. Penelitian kuantitatif ini menggunakan kuesioner yang disampaikan kepada mahasiswa Akuntansi di Perbanas Surabaya yang telah menempuh mata kuliah Perencanaan Pajak pada tahun ajaran 2015/2016. Terdapat 183 responden. Pengujian hipotesis menggunakan analisis regresi. Hasil analisis menunjukkan bahwa hanya variabel Machiavellian yang berpengaruh terhadap persepsi etis dalam penggelapan pajak. Mahasiswa menilai bahwa penggelapan pajak adalah tindakan yang tidak etis. Kondisi tersebut juga didukung oleh persepsi mereka yang belum mengalami kewajiban membayar pajak.
\end{abstract}

\section{PENDAHULUAN}

Adanya pasar bebas yang sedang terjadi telah menghilangkan batas ruang dan waktu setiap individu di dunia. Pasar bebas terjadi dalam berbagai sektor termasuk perekonomian. Indonesia sebagai sebuah negara yang berkembang harus membuka diri dengan baik dalam persaingan di pasar bebas agar dapat meningkatkan pertumbuhan dan pembangunan ekonomi. Kemandirian ekonomi suatu negara diartikan sebagai negara yang tidak bergantung pada negara lain, memiliki jati diri dan karakter yang kuat, serta memiliki ketahanan ekonomi dalam menghadapi berbagai macam krisis (Destianto, 2014). Penggalian potensi penerimaan dalam negeri akan terus ditingkatkan seoptimal mungkin melalui perluasan sumber penerimaan negara non-migas, guna menggantikan pendanaan negara yang bersumber dari utang luar negeri. Salah satu sumber penerimaan dalam negeri yang cukup dominan berasal dari penerimaan 
pajak. Pajak sebagai sumber penerimaan negara memiliki peran besar dalam mewujudkan kemandirian guna meningkatkan pertumbuhan dan pembangunan ekonomi.

Pajak sebagaimana tertuang dalam Undang-Undang Republik Indonesia Nomor 28 Tahun 2007 adalah kontribusi wajib kepada negara yang terutang oleh orang pribadi atau badan yang bersifat memaksa berdasarkan undang-undang, dengan tidak mendapatkan imbalan secara langsung dan digunakan untuk keperluan negara bagi sebesar-besarnya kemakmuran rakyat. Hal ini dapat disimpulkan bahwa membayar pajak bukan hanya merupakan kewajiban, tetapi merupakan hak dari setiap warga negara untuk ikut berpartisipasi dalam bentuk peran serta terhadap pembiayaan negara dan pembangunan nasional. Kontribusi pajak dalam penerimaan negara tertuang dalam susunan APBN tahun 2014 yang menunjukkan rencana total penerimaan yang ditetapkan oleh pemerintah adalah sebesar Rp 1.667,1 triliun yang diantaranya sebesar Rp 1.110,2 triliun berasal dari sektor pajak. Persentase sebesar 66,59\% tersebut menunjukkan bahwa penerimaan sektor pajak memberikan kontribusi yang cukup besar terhadap pendapatan negara. Kondisi ini mengharuskan pemerintah untuk meningkatkan kualitas aspek perpajakan yang ada di Indonesia, baik dari sisi sistem perpajakan maupun sumber daya manusianya.

Bagi wajib pajak, pajak merupakan sebuah biaya atau beban karena akan mengurangi penghasilan yang diterimanya. Wajib pajak yang cenderung ingin meminimalkan besarnya pajak yang akan dibayarnya. Sistem pemungutan pajak self assessment yang berlaku di Indonesia memberi kebebasan wajib pajak untuk menghitung dan memperhitungkan sendiri besaran pajak yang terutang. Hal ini memberi kesempatan kepada wajib pajak untuk dapat meminimalkan jumlah pajak yang terutang melalui mekanisme perencanaan pajak (tax planning) atau melalui cara yang telah jelas diatur dalam peraturan perpajakan (Arifianto, 2013).

Perencanaan pajak yang dikenal masyarakat ada 2 jenis, yaitu penghindaran pajak (tax avoidance) dan penggelapan pajak (tax evasion). Christian (2010) menyatakan bahwa perbedaan antara penghindaran pajak dan penggelapan pajak terletak pada kepatuhannya atas peraturan yang sedang berlaku. Tax avoidance adalah melakukan usaha meminimalkan jumlah pajak terutang dengan memanfaatkan celah peraturan yang ada sehingga dianggap tidak melanggar aturan. Berbe- da dengan tax evasion yang melakukan usaha meminimalkan pajak terutang dengan menggunakan cara yang melanggar hukum.

Banyaknya kasus penggelapan pajak di Indonesia menimbulkan pertanyaan besar, apakah penggelapan pajak ini etis untuk dilakukan? Pandangan masyarakat terhadap sesuatu dikatakan etis atau tidak pun didasarkan pada berbagai alasan sesuai sudut pandang masing-masing. Hal ini memotivasi peneliti untuk melakukan penelitian mengenai persepsi etika atas penggelapan pajak. Peneliti mengambil objek penelitian dari sudut pandang mahasiswa program sarjana yang sekarang sedang menempuh mata kuliah perencanaan pajak. Penelitian ini merupakan melakukan replikasi dari penelitian terdahulu yang dilakukan oleh Nickerson et al. (2009). Adapun rumusan masalah dalam penelitian ini adalah apakah keadilan, sistem perpajakan, diskriminasi dan machiavellian berpengaruh tehadap persepsi mengenai etika atas penggelapan pajak (tax evasion)?. Dan tujuan penelitian ini adalah untuk menguji pengaruh keadilan, sisteam perpajakan, diskriminasi dan machiavellian terhadap persepsi mengenai etika atas penggelapan pajak (tax evasion).

\section{RERANGKA TEORITIS DAN HIPOTESIS PENELITIAN}

Persepsi Mengenai Etika Atas Penggelapan Pajak

Persepsi merupakan pandangan pikiran seseorang yang muncul dari kegiatan mengorganisasikan dalam pikirannya, menafsirkannya, mengalami, dan mengelola pertanda atas segala sesuatu yang terjadi di lingkungannya (Prasetyo, 2010). Rachmadi (2014) mendefinisikan persepsi sebagai respon dari penerimaan kesan melalui penglihatan, sentuhan atau melalui indera lainnya, yang kemudian ditafsirkan berdasarkan pengalaman yang berbeda dari tiap individu, sehingga menghasilkan perilaku yang berbeda pula. Etika adalah nilai-nilai dan norma-norma moral, yang menjadi pegangan bagi seseorang atau suatu kelompok dalam mengatur tingkah lakunya (Bertens, 2000).

Menurut Maryani dan Ludigdo (2001), etika merupakan seperangkat aturan, norma atau pedoman yang mengatur perilaku manusia, baik yang harus dilakukan maupun yang harus ditinggalkan yang dianut oleh sekelompok atau segolongan masyarakat atau profesi. Keraf dan Imam (1991) mengungkapkan etika berkaitan dengan nilai-nilai, tata cara hidup baik, aturan hidup yang baik, dan segala kebiasaan yang dianut dan diwariskan dari satu individu lain atau satu generasi ke generasi lain. Etika merupakan seperangkat prinsip 
moral yang membedakan yang baik dari yang buruk, bidang ilmu yang bersifat normatif karena ia berperan menentukan apa yang harus dilakukan dan apa yang tidak boleh dilakukan oleh seorang individu (Beekum, 2004). Dari definisi di atas dapat disimpulkan bahwa etika merupakan nilai dan norma moral yang mengatur perilaku manusia untuk membedakan sesuatu yang baik dan yang buruk. Etika berkaitan erat dengan kebiasaan hidup yang baik.

Etika pajak merupakan tindakan untuk mematuhi peraturan perpajakan atau undangundang perpajakan yang dibuat oleh pemerintah, dalam hal ini wajib pajak harus rutin dalam membayar pajak karena dengan membayar pajak maka pembangunan akan terlaksana dengan baik (Izza dan Hamzah, 2009). Suminarsasi dan Supriyadi (2011), menjelaskan etika pajak merupakan peraturan dimana orang atau kelompok orang yang menjalani kehidupan dalam lingkup perpajakan, bagaimana mereka melaksanakan kewajiban perpajakannya, apakah sudah benar, salah, baik, atau buruk.

Penggelapan pajak (tax evasion) adalah usaha yang dilakukan oleh wajib pajak untuk meringankan beban pajak dengan cara yang tidak legal atau melanggar undang-undang (Mardiasmo, 2011). Dalam hal ini, wajib pajak mengabaikan ketentuan formal perpajakan yang menjadi kewajibannya, memalsukan dokumen, atau mengisi data dengan tidak lengkap dan tidak benar.

Penggelapan pajak (tax evasion) adalah tindak pidana karena merupakan manipulasi subjek dan objek pajak untuk memperoleh penghematan pajak dengan melanggar hukum, dan penggelapan pajak boleh dikatakan merupakan suatu hal yang melekat pada setiap sistem pajak yang berlaku di hampir setiap daerah (Duadji, 2008). Penggelapan pajak merupakan usaha untuk mengecilkan beban pajak dengan cara tidak legal atau melanggar peraturan yang berlaku. Berdasarkan penelitian McGee (2006), terdapat beberapa alasan orang melakukan penggelapan pajak, antara lain sistem pemerintahan yang buruk, sistem pajak yang tidak adil, uang pajak tidak digunakan dengan baik, tarif pajak yang terlalu tinggi tidak sebanding dengan manfaatnya, dan adanya kesempatan untuk melakukan karena sistem hukum yang lemah. Penggelapan pajak yang dilakukan secara tidak legal akan membawa dampak negatif dalam berbagai bidang (Muhammad Zain, 2007), antara lain: a) akan menimbulkan pos kerugian bagi kas negara, b) adanya persaingan yang tidak sehat antar pengusaha, c) akan menimbulkan suatu kebiasaan untuk selalu melanggar undang-undang, terlebih lagi apabila tindakan ini tidak diketahui oleh fiskus.

McGee (2006) menemukan bahwa beberapa negara mengatakan penggelapan pajak tidak etis, namun mereka juga menganggap penggelapan pajak kadang-kadang dipandang etis tergantung pada fakta-fakta dan keadaan atau bahkan dipandang selalu etis. Dari penjelasan di atas dapat disimpulkan bahwa persepsi mengenai etika atas penggelapan pajak merupakan suatu proses individu dalam menerima, mengorganisasikan, serta mengartikan praktik penggelapan pajak yang dipengaruhi oleh lingkungan sosial di sekitarnya. Dalam hal ini individu akan mengartikan penggelapan pajak merupakan tindakan tidak etis, kadang-kadang etis, atau bahkan selalu etis.

\section{Keadilan}

Prinsip keadilan menurut Siahaan (2010) terbagi menjadi tiga pendekatan, yaitu: a) Prinsip manfaat dimana keadilan pajak dapat dicapai apabila kontribusi yang diberikan setiap wajib pajak sesuai dengan manfaat yang diperolehnya dari jasa-jasa pemerintah, b) Prinsip kemampuan dimana perekonomian membutuhkan suatu jumlah penerimaan pajak tertentu dan setiap wajib pajak diminta untuk membayar sesuai dengan kemampuannya, c) Prinsip keadilan horizontal menjelaskan wajib pajak yang berada dalam kondisi yang sama diperlakukan sama dalam pengenaan dan pemungutan pajaknya. Pemungutan pajak dikatakan adil apabila orang-orang dengan tambahan kemampuan ekonomis yang berbeda dikenakan pajak penghasilan yang berbeda setara dengan perbedaannya.

Keadilan memiliki perspektif yang sangat luas antara masing-masing individu. Negara memiliki kewajiban untuk mewujudkan keadilan tersebut meskipun banyak perspektif yang mendasarinya. Negara harus mampu mencapai kondisi dimana semua masyarakat membayar pajak sesuai dengan kemampuan yang dimiliki dan kondisi ini mampu mendukung kepentingan negara meningkatkan sumber penerimaan negara.

Pemerintah dapat dikatakan adil dalam memperlakukan masyarakatnya apabila uang pajak yang dibayarkan oleh masyarakat digunakan sebagaimana mestinya, yaitu untuk pengeluaran umum negara, tidak untuk kepentingan pribadi pemerintah (Nickerson et al., 2009). Pemerintah juga dapat dikatakan adil apabila pengenaan dan pemungutan pajak terhadap masyarakat diperlakukan dengan sama, kondisi ini akan terlihat dari 
undang-undang pajak yang telah disusun dan dilaksanakan (Suminarsasi dan Supriyadi, 2011). Semakin tinggi keadilan yang dilakukan oleh pemerintah, maka masyarakat akan semakin percaya terhadap kinerja pemerintah. Hal ini akan mendorong kemauan masyarakat untuk membayar pajak dan mempercayai pemerintah dalam mengelola dana yang bersumber dari pajak (Rahman, 2013).

Manfaat yang banyak dirasakan masyarakat atas fasilitas negara yang tersedia akan meningkatkan kepercayaan terhadap pemerintah dalam mengelola dana yang bersumber dari pajak. Masyarakat akan beranggapan bahwa penggelapan pajak yang melanggar aturan dan merugikan masyarakat secara luas merupakan tindakan yang tidak etis untuk dilakukan. Penelitian yang dilakukan oleh Nickerson et al. (2009), McGee et al. (2007), Handyani dan Cahyonowati (2014), dan Ginanjar (2014) menunjukkan bahwa keadilan berpengaruh negatif dan signifikan terhadap persepsi mengenai etika atas penggelapan pajak, yaitu semakin tinggi tingkat keadilan di pemerintahan suatu negara, maka masyarakatnya akan memliki persepsi bahwa penggelapan pajak merupakan tindakan yang tidak etis.

\section{Sistem Adiministrasi Perpajakan}

Salah satu reformasi di bidang perpajakan ditandai dengan ditetapkannya vsi dari DJP yaitu menjadi model pelayanan masyarakat yang menyelenggarakan sistem dan manajemen perpajakan kelas dunia yang dipercaya dan dibanggakan masyarakat. DJP menetapkan misinya yang salah satunya adalah untuk menghimpun penerimaan dalam negeri dari sektor pajak yang mampu menunjang kemandirian pembiayaan pemerintah berdasarkan Undang-Undang Perpajakan dengan tingkat efektifitas dan efisiensi yang tinggi.

Penilaian keberhasilan penerimaan pajak dapat dilihat dari pencapaian sasaran administrasi perpajakan, yaitu peningkatan kepatuhan para pembayar pajak dan pelaksanaan ketentuan perpajakan secara seragam untuk mendapatkan penerimaan maksimal dengan biaya yang optimal. Program dan kegiatan reformasi administrasi perpajakan diwujudkan dalam penerapan sistem administrasi perpajakan modern yang memiliki ciri khusus antara lain struktur organisasi berdasarkan fungsi, perbaikan pelayanan bagi setiap wajib pajak melalui pembentukkan account representative dan complaint center untuk menampung keberatan wajib pajak.

Selain itu, sistem administrasi perpajakan modern juga merangkul kemajuan teknologi terba- ru diantaranya melalui pengembangan Sistem Informasi Perpajakan (SIP) yang semula berdasarkan pendekatan fungsi menjadi Sistem Administrasi Perpajakan Terpadu (SAPI) yang dikendalikan oleh case management system dalam wrkflow system dengan berbagai modul otomatisasi kantor serta berbagai pelayanan berbasis $e$-system seperti $e$-SPT, $e$ Fililng, e-Payment, Taxpayer's Account,e-Registration, dan $e$-Counceling. Reformasi sistem administrasi ini diharapkan mekanisme kontrol menjadi lebih efektif ditunjang oleh adanya penerapan kode etik pegawai DJP yang mengatur perilaku pegawai dalam melaksanakan tugasnya. Dimensi sistem administrasi perpajakan modern, yaitu: a) Pelayanan satu pintu melalui Account Representative. b) Penerapan Complaint Center, c) Penyederhanaan prosedur administrasi dan meningkatkan standar waktu dan kualitas pelayanan dan pemeriksaan pajak, d) Dukungan teknologi sistem informasi dalam memberikan pelayanan, pengawasan, pemeriksaan dan penagihan pajak.

Sistem perpajakan dapat dikatakan baik apabila prosedur perpajakan terkait penghitungan, pembayaran, dan pelaporan dapat dilakukan dengan mudah. Fiskus harus berperan aktif dalam mengawasi dan melaksanakan tugasnya dengan integritas yang tinggi. Sebaliknya, sistem perpajakan dikatakan tidak baik apabila di dalam pelaksanaannya fiskus melakukan kecurangan seperti korupsi yang sangat merugikan masyarakat. Kecurangan yang terjadi di dalam sistem ini akan menimbulkan rasa tidak percaya masyarakat terhadap pemerintah (Nickerson et al., 2009). Semakin baik sistem perpajakan yang berlaku, maka masyarakat akan semakin merasa mudah dan dilayani dengan baik oleh pemerintah sehingga kepercayaan masyarakat terhadap pemerintah pun akan semakin meningkat (Suminarsasi dan Supriyadi, 2011). Sukarelawati (2015) menjelaskan penerapan e-tax dalam pajak daerah di Kota Malang meningkatkan kemauan wajib pajak dalam membayar pajak. Penelitian sebelumnya yang dilakukan oleh Nickerson et al. (2009), McGee et al. (2007), Suminarsasi dan Supriyadi (2011), Rahman (2013), Handyani dan Cahyonowati (2014), dan Ginanjar (2014) menunjukkan bahwa sistem perpajakan berpengaruh negatif dan signifikan terhadap persepsi mengenai etika atas penggelapan pajak. Semakin baik sistem perpajakan yang berlaku, maka persepsi masyarakat menganggap penggelapan pajak merupakan perilaku yang tidak etis. 


\section{Diskriminasi}

Undang-Undang Nomor 39 Tahun 1999 tentang Hak Asasi Manusia Pasal 1 ayat (3) menyatakan bahwa diskriminasi adalah setiap pembatasan, pelecehan, atau pengucilan yang didasarkan perbedaan manusia atas dasar agama, suku, ras, etnik, kelompok, golongan, status sosial, status ekonomi, jenis kelamin, bahasa, dan keyakinan politik, yang berakibat pengangguran, penyimpangan atau penghapusan pengakuan, pelaksanaan atau penggunaan hak asasi manusia dan kebebasan dasar dalam kehidupan, baik individual maupun kolektif dalam bidang politik, ekonomi, hukum, sosial, budaya, dan aspek kehidupan yang lain. Diskriminasi sebagai pembedaan perlakuan terhadap sesama warga negara berdasarkan warna kulit, golongan, suku, ekonomi, agama, dan sebagainya.

Pemerintah dikatakan melakukan diskriminasi apabila kebijakan yang diterapkan hanya menguntungkan pihak tertentu saja. Adanya diskriminasi yang dilakukan oleh pemerintah akan mendorong sikap masyarakat untuk tidak setuju dengan kebijakan yang berlaku (Nickerson et al., 2009). Beberapa peraturan perpajakan yang berlaku di Indonesia dinilai sebagai bentuk diskriminasi pemerintah, salah satunya adalah zakat yang diperbolehkan sebagai pengurang pajak karena ini hanya diberlakukan untuk masyarakat yang beragama Islam saja (Suminarsasi dan Supriyadi, 2011). Selain itu, adanya Peraturan Pemerintah Nomor 46 Tahun 2013 dimana pajak final dikenakan sebesar $1 \%$ terhadap penghasilan bruto juga dinilai sebagai bentuk diskriminasi karena banyak merugikan pengusaha kecil menengah yang belum mapan dalam usahanya.

Semakin banyak peraturan perpajakan yang dianggap sebagai bentuk diskriminasi yang merugikan, maka masyarakat akan cenderung untuk tidak patuh terhadap aturan. Ketidakpatuhan ini dapat berakibat pada masyarakat yang enggan membayar pajak (Arifianto, 2013). Penelitian yang dilakukan oleh Nickerson et al. (2009), McGee et al. (2007), Suminarsasi dan Supriyadi (2011), dan Rahman (2013) menunjukkan bahwa diskriminasi berpengaruh positif dan signifikan terhadap persepsi mengenai etika atas penggelapan pajak. Semakin banyak bentuk diskriminasi dalam suatu negara, maka masyarakatnya memiliki persepsi bahwa penggelapan pajak etis dilakukan.

\section{Machiavellian}

Prinsip Machiavelli menyebutkan hal-hal seperti norma, moralitas, agama, budaya dan tuntutan moral dan hati nurani lebih diabaikan. Sifat
Machiavellian ini merupakan sifat yang memiliki dampak buruk bagi suatu profesi, terutama profesi akuntan. Sifat Machiavellian memiliki sikap manipulatif. Machiavellianisme adalah tingkat di mana seorang individu pragmatis, mempertahankan jarak emosional dan yakin bahwa hasil lebih penting daripada proses (Stephen and Timothy, 2008:139). Kepribadian Machiavellian dicirikan dengan kehendak untuk memanipulasi dan hasrat akan kekuasaan dengan mudah menggunakan politik sebagai sarana untuk memperjuangkan kepentingannya sendiri (Stephen and Timothy, 2008:151).

Machiavellian berkaitan dengan individu yang manipulatif, menggunakan perilaku persuasif untuk mencapai tujuan pribadi dan biasanya agresif (Kelly, 2001). Setiap manusia yang memutuskan untuk bertindak baik, pasti akan hancur. Jika seseorang ingin tetap berkuasa, maka ia harus belajar menjadi orang yang tidak baik dan harus memiliki kemampuan untuk memanfaatkan peluang yang ada. Kepribadian Machiavellian sebagai suatu kepribadian antisosial, yang tidak memperhatikan moralitas konvensional dan mempunyai komitmen ideologis yang rendah (Vena dan Agnes, 2006). Sifat Machiavellian ini merupakan sifat yang memiliki dampak buruk bagi suatu profesi terutama profesi akuntan. Seseorang yang memiliki kepribadian machiavellian akan semakin mampu memanfaatkan peluang yang ada guna mencapai tujuan dirinya, salah satunya berusaha untuk menggunakan berbagai cara agar pembayaran pajak pada negara semakin kecil.

\section{Kerangka Pemikiran}

Pada penelitian ini diuji keseluruhan variabel yang terdapat dalam penelitian terdahulu, yaitu pengaruh keadilan, sistem perpajakan, diskriminasi dan machiavellian terhadap persepsi mengenai etika atas penggelapan pajak.

Perumusan Hipotesis

H1 : Keadilan berpengaruh terhadap persepsi mengenai etika atas penggelapan pajak (tax evasion).

H2 : Sistem perpajakan berpengaruh terhadap persepsi mengenai etika atas penggelapan pajak (tax evasion).

H3 : Diskriminasi berpengaruh terhadap persepsi mengenai etika atas penggelapan pajak (tax evasion).

H4 : Machiavellian berpengaruh terhadap persepsi etis atas penggelapan pajak (tax evasion) 


\section{METODE PENELITIAN \\ Rancangan Penelitian}

Penelitian ini merupakan penelitian kuantitatif yang menggunakan data primer. Data penelitian diperoleh dari penyebaran kuesioner kepada responden secara langsung. Responden penelitian adalah mahasiswa program studi sarjana akuntansi STIE Perbanas Surabaya yang sedang menempuh mata kuliah Perencanaan Pajak. Metode pengujian yang dilakukan adalah regresi berganda.

\section{Definisi Operasional Variabel Penelitian}

Variabel penelitian ini adalah keadilan, sistem administrasi perpajakan, diskrimasi, machiavellian dan persepsi mengenai etika atas penggelapan pajak. Variabel pertama yaitu keadilan dalam hal yang berhubungan dengan penggunaan dana pajak secara positif. Keadilan untuk mendeskripsikan suatu kondisi dimana masyarakat harus mendapat perlakuan yang sama dalam pengenaan dan pemungutan pajak oleh negara.

Variabel kedua yaitu sistem administrasi perpajakan yang didefinisikan dalam lingkup tarif pajak dan penggunaan dana pajak secara negatif. Sistem perpajakan dikatakan baik apabila terdapat kemudahan dalam prosedur perpajakan yang ada, terkait penghitungan, pembayaran, dan pelaporan.

Variabel ketiga yaitu diskriminasi yang menjelaskan diskriminasi dalam lingkup perlakuan pemerintah yang berbeda untuk kondisi tertentu. Pengukuran variabel keadilan, sistem administrasi perpajakan dan diskriminasi menggunakan skala likert empat poin yang mengacu pada penelitian Nickerson et al. (2009) dan Rahman (2013).

Variabel keempat yaitu Machiavellian merupakan sikap manipulatif dan juga menyatakan bahwa norma, moralitas, agama, budaya dan tuntutan moral dan hati nurani lebih diabaikan. Persepsi Sifat Machiavellian diukur dengan skala Mach IV yang dikembangkan oleh Christie dan Geis (1970). Variabel kelima yaitu persepsi mengenai etika atas penggelapan pajak. Penggelapan pajak kadang-kadang dipandang etis atau bahkan selalu etis. Pandangan tersebut tentunya dilandasi oleh alasan-alasan dari fenomena yang ada di masyarakat.

\section{Data dan Pengumpulan Data}

Metode pengumpulan data dalam penelitian ini adalah metode survei dalam bentuk kuesioner. Peneliti melakukan penyebaran kuesioner secara langsung pada mahasiswa aktif
Prodi Sarjana Akuntansi STIE Perbanas Surabaya yang sedang menempuh mata kuliah Perencanaan Pajak pada Semester Gasal 2015-2016.

\section{Teknik Analisis}

Sebelum dilakukan pengujian hipotesis, dilakukan uji reabilitas dengan menggunakan nilai Cronbach's Alpha. Kemudian dilakukan uji asumsi klasik yang meliputi 1) Uji Multikolinearitas yang dilakukan dengan melihat nilai VIF, 2) Uji Normalitas, dengan menggunakan uji Kolmogorov Smirnov. Uji hipotesis dalam penelitian ini dilakukan menggunakan analisis regresi.

\section{HASIL DAN PEMBAHASAN \\ Gambaran Umum Responden}

Penelitian ini merupakan penelitian kuantitatif dengan menggunakan data primer dengan penyebaran kuesioner langsung pada responden. Responden penelitian ini adalah mahasiswa Program Studi Sarjana Akuntansi yang sedang memprogram mata kuliah Perencanaan Pajak Semester Gasal 2015-2016 sebanyak 186 orang. isian kuesioner yang tidak lengkap sebanyak 3 orang sehingga data yang bisa diolah ada 183 .

Hasil pengumpulan data menyatakan bahwa dilihat dari jenis kelamin sebanyak 145 responden $(79 \%)$ adalah perempuan, dan sisanya 38 responden $(21 \%)$ adalah laki-laki. Dilihat dari bidang peminatan menunjukkan 105 responden (57\%) memilih peminatan Akuntansi Keuangan, 42 responden $(23 \%)$ memilih peminatan Akuntansi Perbankan, 29 responden (16\%) memilih peminatan Audit dan Perpajakan, sedangkan sisanya 7 responden (4\%) memilih peminatan SIA dan Akuntansi Manajemen. Dilihat dari prestasi akademik menunjukkan 6 responden $(3 \%)$ memiliki IPK di bawah 2,75; sebanyak 21 responden (11\%) memiliki IPK antara 2,75-3,00; sebanyak 71 responden (39\%) memiliki IPK antara 3,01-3,50 dan sisanya 85 responden $(46 \%)$ memiliki IPK di atas 3,50.

\section{Deskripsi Variabel}

Variabel dalam penelitian ini adalah keadilan, sistem administrasi perpajakan, diskriminasi, machiavellian dan persepsi mengenai etika atas penggelapan pajak. Pada variabel keadilan menunjukkan rata-rata jawaban responden sebesar 2,90 artinya responden setuju bahwa masyarakat harus mendapat perlakuan yang sama atas pengenaan dan pemungutan pajak oleh negara. Variabel sistem administrasi perpajakan menunjukkan rata-rata jawaban responden sebesar 3,07 artinya setuju bahwa sistem administrasi perpajakan yang telah diban- 
gun oleh DJP mampu mempermudah wajib pajak melaksanakan kewajiban perpajakannya.

Variabel diskriminasi menunjukkan ratarata responden sebesar 3,10 artinya setuju bahwa pemerintah masih menetapkan kebijakan tertentu yang menguntungkan pihak tertentu. Variabel machiavellian menunjukkan rata-rata responden sebesar 3,07 artinya prinsip machiavellian bersifat manipulatif dan cenderung merupakan peluang bagi masyarakat untuk bisa meminimalisir pembayaran pajak kepada negara. Variabel persepsi mengenai etika atas penggelapan pajak menunjukkan ratarata jawaban responden sebesar 3,17 artinya masyarakat mempersepsikan bahwa penggelapan pajak adalah perbuatan yang melanggar aturan perpajakan dan tidak etis.

\section{Hasil Pengujian}

Pengujian awal yang dilakukan adalah uji reliabilitas atas 43 item pernyataan menunjukkan sebanyak 34 item pernyataan yang dinyatakan reliabel (karena Cronbach's Alpha >0,60) dan 9 item pernyataan tidak diikutkan dalam pengujian berikutnya. Nilai reliabilitas variabel keadilan sebesar 0,6498, variabel sistem administrasi perpajakan sebesar 0,6887, variabel machiavellian sebesar 0,6275 dan variabel diskriminasi sebesar 0,6262. Sedangkan variabel persepsi mengenai etika atas penggelapan pajak tidak diuji reliabilitas karena skala yang digunakan adalah nominal.

Uji asumsi klasik yang digunakan adalah uji normalitas dan uji multikolinearitas. Uji normalitas menunjukkan bahwa nilai kolmogorov smirnov sebesar 1,119 dengan tingkat signifikansi 0,163 (di atas 0,05 ) yang menyatakan bahwa data terdistribusi normal. Uji multikolinearitas menunjukkan bahwa nilai VIF dari masing-masing varibel $<0,1$ yang menyatakan tidak terjadi gejala multikolinearitas. Setelah itu, dilakukan uji F dan hasilnya menunjukkan nilai signifikansi sebesar 0,014 dan adjusted R Square sebesar 0,168 yang menyatakan model fit. Sedangkan hasil uji $t$ dan koefisien adjusted R Square sebagai berikut:
Tabel 1. Hasil Pengujian Regresi

\begin{tabular}{lccl}
\hline Variabel & $\begin{array}{l}\text { Adj R } \\
\text { Squar } \\
\text { e }\end{array}$ & $\begin{array}{l}\text { Signifi- } \\
\text { kansi }\end{array}$ & $\begin{array}{l}\text { Hasil } \\
\text { Pengu- } \\
\text { jian }\end{array}$ \\
\hline Keadilan & 0,004 & 0.943 & $\begin{array}{l}\text { Ho dite- } \\
\text { rima }\end{array}$ \\
$\begin{array}{l}\text { Sistem ad- } \\
\text { ministrasi } \\
\text { perpajakan }\end{array}$ & 0,005 & 0,629 & $\begin{array}{l}\text { Ho dite- } \\
\text { rima }\end{array}$ \\
$\begin{array}{l}\text { Diskrimi- } \\
\text { nasi } \\
\text { machiavel- }\end{array}$ & 0,003 & 0,933 & $\begin{array}{l}\text { Ho dite- } \\
\text { rima } \\
\text { lian }\end{array}$ \\
\hline
\end{tabular}

\section{Pembahasan}

Hasil pengujian dalam penelitian ini menunjukkan bahwa hanya variabel machiavellian yang memiliki pengaruh signifikan terhadap persepsi mengenai etika atas penggelapan pajak, sedangkan variabel keadilan, sistem administrasi perpajakan dan diskriminasi memiliki pengaruh tidak signifikan terhadap persepsi mengenai etika atas penggelapan pajak. Penggelapan pajak (tax evasion) merupakan salah satu upaya wajib pajak untuk meminimalisir pembayaran pajak yang melanggar ketentuan perpajakan. Penggelapan pajak dianggap perbuatan yang tidak etis, namun penggelapan pajak ini terkadang dilakukan oleh wajib pajak karena ketidaktahuan tentang ketentuan perpajakan, kealpaan ketentuan perpajakan dan adanya perbedaan persepsi antara wajib pajak dan fiskus terkait ketentuan perpajakan. Persepsi mahasiswa dalam penggelapan pajak juga menyatakan bahwa hal tersebut tidak etis. Penggelapan pajak cenderung dilakukan dalam hal perhitungan dan pembayaran pajak, sedangkan dalam hal pemenuhan persyaratan kewajiban perpajakan cenderung ditaati misalkan persyaratan ber-NPWP atau PKP, ketentuan formal pengisian SSP dan SPT, ketentuan tanggal pembayaran dan pelaporan.

Machiavellian adalah sikap egois seseorang yang selalu berusaha untuk memanfaatkan peluang demi kepentingan diri sendiri. Persepsi mahasiswa menyatakan bahwa seseorang khususnya wajib pajak selalu ingin memanfaatkan ketentuan perpajakan sebagai peluang untuk bisa meminimalisir pembayaran pajak, sehingga mereka berpandangan bahwa penggelapan pajak yang dilakukan bukan perbuatan etis. Tindakan penggelapan pajak dianggap wajar karena mereka termotivasi pada 3 hal, yaitu 1) adanya kebijaksanaan perpajakan (Tax Policy), bahwa ketentuan perpajakan mengandung alternatif dari berbagai sasaran yang hendak dituju oleh administrasi perpajakan, 2) adanya ketentuan 
perpajakan (Tax Law) yang menunjukkan bahwa berbagai aturan perpajakan (UU, KMK, PP, SE) yang masih menunjukkan pertentangan karena sebenarnya mengandung kepentingan dari si pembuat aturan tersebut, 3) adanya administrasi perpajakan (Tax Adminstrasion) yang sebenarnya memberikan peluang wajib pajak untuk meminimalkan pembayaran pajak karena masih ada perlakuan yang berbeda misalkan perlakuan tarif, perlakuan obyek pajak.

Persepsi mahasiswa ini belum didasarkan atas apa yang terjadi sesungguhnya, artinya mereka belum menjadi wajib pajak sehingga mereka belum memiliki pengalaman dalam menghitung, memperhitungkan, membayar dan melaporkan pajak terutang. Pada penelitian ini menunjukkan bahwa keadilan, sistem administrasi perpajakan dan diskriminasi memiliki pengaruh tidak signifikan terhadap persepsi mengenai etika atas penggelapan pajak. Kondisi ini didasari bahwa 1) ketentuan perpajakan yang berlaku saat ini dianggap sesuatu yang bersifat normatif atau sesuatu yang harus ditaati tanpa harus dilanggar, 2) mereka juga bukan sebagai wajib pajak potensial yang memiliki kepentingan besar atas apa yang dibayarkan sehingga mereka tidak merasakan adanya diskriminasi dalam perlakuan perpajakan, 3) mereka belum mengerti bahkan belum terlibat langsung dalam sistem administrasi perpajakan sehingga mereka belum merasakan pelayanan petugas pajak, 4) dukungan mata kuliah lain (Etika dan Pengembangan Kepribadian, Etika Profesi Akuntan) dan Pengembangan Softskill di lingkungan STIE Perbanas Surabaya mendukung upaya untuk tidak melakukan penggelapan pajak. .

\section{KESIMPULAN}

Penerimaan negara yang bersumber dari pajak saat ini menduduki porsi terbesar dalam Anggaran Penerimaan dan Belanja Negara (APBN). Berbagai upaya reformasi telah dilakukan oleh Pemerintah dalam meningkatkan target penerimaan negara. Di sisi lain, wajib pajak juga berupaya agara mampu meminimalisir pembayaran pajak. Salah satunya adalah penggelapan pajak (Tax Evasion). Penggelapan pajak selama ini dipersepsikan sebagai perbuatan yang tidak etis karena melanggar ketentuan perpajakan yang ada. Persepsi ini dipengaruhi adanya faktor keadilan, sistem administrasi perpajakan, diskriminasi dan machiavellian.

Hasil penelitian ini menunjukkan bahwa hanya variabel machiavellian yang memiliki pengaruh signifikan terhadap persepsi mengenai etika atas penggelapan pajak. Pada penelitian ini menun- jukkan bahwa keadilan, sistem administrasi perpajakan dan diskriminasi memiliki pengaruh tidak signifikan terhadap persepsi mengenai etika atas penggelapan pajak. Mahasiswa mempersepsikan bahwa penggelapan pajak sebagai perbuatan yang tidak etis. Kondisi ini didasari bahwa 1) ketentuan perpajakan yang berlaku saat ini dianggap sesuatu yang bersifat normatif atau sesuatu yang harus ditaati tanpa harus dilanggar, 2) mereka juga bukan sebagai wajib pajak potensial yang memiliki kepentingan besar atas apa yang dibayarkan sehingga mereka tidak merasakan adanya diskriminasi dalam perlakuan perpajakan, 3) mereka belum mengerti bahkan belum terlibat langsung dalam sistem administrasi perpajakan sehingga mereka belum merasakan pelayanan petugas pajak, 4) dukungan mata kuliah lain (Etika dan Pengembangan Kepribadian, Etika Profesi Akuntan) dan Pengembangan Softskill di lingkungan STIE Perbanas Surabaya mendukung upaya untuk tidak melakukan penggelapan pajak.

\section{REFERENSI}

Arifianto, W, 2013. Tax Avoidance, Tax Planning, Tax Evasion, dan Anti Avoidance Rule. (http:/ / wirzaarifianto.wordpress.com/20 13/02/04/tax-avoidance-tax-planningtax-evasion-dan-anti-avoidance-rule/), diakses 10 Juni 2014.

Beekum, F. I, 2004. Etika Bisnis Islami. Yogyakarta: Pustaka Pelajar.

Bertens, K, 2000. Pengantar Etika Bisnis. Jakarta: Penerbit Kanisius.

Christian K, I, 2010. Perbedaan Penghindaran Pajak Dengan Penggelapan $\mathrm{Pa}$ jak.(http:/ / konsultasibelajarpajak.blogspo t.com/2010/01/perbedaanpenghindaran-pajak-dengan.html), diakses 31 Januari 2015.

Destianto, L, 2014. Aviliani: Jati Diri Bangsa Terletak pada Kemandirian Ekonomi. (http://www.uinjkt.ac.id/index.php/arsi p-berita-utama/1358-avilliani-jati-diribangsa-terletak-pada-kemandirianekonomi.html), diakses 7 Desember 2014.

Duadji, S, 2008. Selayang Pandang: Praktik Pencucian Uang dan Kejahatan Asal. Bandung: Books Terrace \& Library. 
Ginanjar, R, 2014. Pengaruh Keadilan dan Sistem Pemungutan Pajak Terhadap Persepsi Wajib Pajak Mengenai Etika Penggelapan Pajak (Studi Pada Wajib Pajak Badan di KPP Sukabumi). Paper Seminar Nasional . Bandung: Program Studi Akuntansi Fakultas Pendidikan Ekonomi dan Bisnis Universitas Pendidikan Indonesia.

Ghozali, I, 2013. Apilkasi Analisis Multivariate Dengan Program IBM SPSS Update PLS Regresi Edisi 7. Semarang: BP Universitas Diponegoro.

Handyani M, A. \& Cahyonowati, N. 2014. Analisis Faktor-Faktor Yang Mempengaruhi Persepsi Wajib Pajak Mengenai Penggelapan Pajak. Diponegoro Journal of Accounting. Volume 3, Nomor 3; 1-7.

Izza, I. A. N. \& Hamzah, A. 2009. Etika Penggelapan Pajak Perspektif Agama: Sebuah Studi Interpretatif. Simposium Nasional Akuntansi, Palembang. Volume 12.

Richmond, A, 2001, “Ethical Reasoning, Machiavellian Behaviour, and Gender:The Impact on Accounting Student's Ethical Decision Making" Dissertation submitted to the faculty of the Virginia Polytechnic Institute and State University in partial fulfillment of the requirement for the degree of Doctor of Philosophy in General Business tidak dipublikasi

Keraf, A. S. \& Imam, R.H. 1991. Etika Bisnis: Membangun Citra Bisnis sebagai Profesi Luhur. Yogyakarta: Penerbit Kanisius.

Mardiasmo. 2011. Perpajakan. Jakarta: Penerbit ANDI.

Maryani, T. \& Ludigdo, U, 2011. Survey atas Faktor-faktor yang Mempengaruhi Sikap dan Perilaku Etis Akuntan. Jurnal TEMA, Volume 2, Nomor; 49-62.

McGee, R.W., Nickerson, I., Pleshko, L. P, 2006. A Comparative Study Of Tax Evasion In Six Countries. Allies Academies International Conference. Volume 12, Nomor 1; 25- 30.
Muhammad Zain, 2007. Manajemen Perpajakan. Jakarta: Salemba Empat

Nickerson, I., Pleshko, L., McGee, R. W, 2009. Presenting The Dimensionality Of An Ethics Scale Pertaining To Tax Evasion. Journal of Legal, Ethical and Regulatory Issues. Volume 12, Nomor 1; 1-14.

Prasetyo, S, 2010. Persepsi Etis Penggelapan Pajak Bagi Wajib Pajak Di Wilayah Surakarta. Paper Seminar Nasional. UNDIP.

Rachmadi, W, 2014. Faktor-Faktor yang Mempengaruhi Persepsi Wajib Pajak Orang Pribadi Atas Perilaku Penggelapan Pajak. $\mathrm{Pa}$ per Seminar Nasional. UNDIP.

Rahman, I. S, 2013. Pengaruh Keadilan, Sistem Perpajakan, Diskriminasi, dan Kemungkinan Terdeteksi Kecurangan Terhadap Persepsi Wajib Pajak Mengenai Etika Penggelapan Pajak (Tax Evasion). Prosiding Simposium Nasional Perpajakan 4.

Siahaan, M. P. 2010, Hukum Pajak Elementer. Yogyakarta: Penerbit Graha Ilmu.

Sukarelawati, E, 2015. Perolehan Pajak Kota Malang Kelebihan $R p \quad 17,5$ Milyar. (http:// www.antarajatim.com/lihat/beri ta/148641/perolehan-pajak-kota-malangkelebihan-rp175-miliar), diakses 7 Januari 2015.

Suminarsasi, W. \& Supriyadi, 2011. Pengaruh Keadilan, Sistem Perpajakan, dan Diskriminasi Terhadap Persepsi Wajib Pajak Mengenai Etika Penggelapan Pajak (Tax Evasion). Tesis. Yogyakarta: Jurusan Akuntansi Magister Sains Fakultas Ekonomika dan Bisnis Universitas Gadjah Mada.

Robbins, S. P \& Judge, T. A, 2008, Perilaku Organisasi. Edisi 12. Buku 1 dan 2. Salemba Empat

Undang-Undang Republik Indonesia Nomor 28 Tahun 2007 Tentang Perubahan Ketiga Atas Undang-Undang Nomor 6 Tahun 1983 Tentang Ketentuan Umum dan Tata Cara Perpajakan. 
Undang-Undang Nomor 39 Tahun 1999 tentang Hak Asasi Manusia Pasal 1 ayat (3)

Vena Purnamasari dan Agnes A Chrismastuti. 2006. "Dampak Reinforcement Contigency terhadap hubungan sifat Machiavellian dan Perkembangan Moral". Simposium Nasional Akuntansi 9 Padang 